Revta brasil. Bot., São Paulo, V.24, n.1, p.99-108, mar. 2001

\title{
Ecological distribution of Cyanophyceae in lotic ecosystems of São Paulo State
}

\author{
LUIS HENRIQUE Z. BRANCO ${ }^{1,3}$, ORLANDO NECCHI JÚNIOR ${ }^{1}$ \\ and CIRO CESAR Z. BRANCO ${ }^{2}$
}

(received: April 20, 2000; accepted: December 20, 2000)

\begin{abstract}
Ecological distribution of Cyanophyceae in lotic ecosystems of São Paulo State). A hundred seventy two stream reaches from six distinct natural regions (parts of biomes or geological areas) in São Paulo State (Atlantic Rainforest, Cerrado, Hard Water regions, Northwest region, Subtropical Rainforest, and Tropical Rainforest) were searched for the most representative macroscopic Cyanophyceae of phytobenthic communities. Selected ecological parameters were analyzed in each stream segment: conductance, current velocity, oxygen saturation, $\mathrm{pH}$, turbidity, and water temperature. Algal abundance was evaluated as percentage cover. Thirthy four cyanophyte taxa were identified and Phormidium retzii was the most widespread species throughout the State, occurring in all studied regions, except in hard water areas, and was negatively correlated to conductance. The subtropical Rainforest region presented the highest mean species richness per site, whereas the tropical Rainforest region had the highest abundance (percentage cover) of blue-green algae. Correlation tests revealed that conductance was significantly and negatively related to variations in abundance and richness of cyanophyte in streams of São Paulo State. This relationship probably reflects the ability of blue-green algae to grow at medium to low ion content and to take advantage under nutrient stress conditions.
\end{abstract}

RESUMO - (Distribuição ecológica de Cyanophyceae em ambientes lóticos do estado de São Paulo). Cento e setenta e dois trechos de riachos de seis regiões naturais (partes de biomas ou áreas geológicas) no estado de São Paulo (Mata Atlântica, Cerrado, regiões de Águas Duras, região noroeste do estado, Floresta Subtropical e Floresta Tropical) foram investigados com relação às Cyanophyceae macroscópicas mais representativas nas comunidades algais. Condutividade, velocidade da correnteza, saturação de oxigênio, $\mathrm{pH}$, turbidez e temperatura foram os parâmetros ecológicos analisados para a avaliação da distribuição dos táxons entre os segmentos de riachos. A abundância das populações foram avaliadas através de suas porcentagem de cobertura. Trinta e quatro táxons foram identificados, sendo que Phormidium retzii foi a espécie melhor distribuída no estado, ocorrendo em todas regiões estudadas, exceto em regiões de águas duras e sua ocorrência revelou correlação negativa com condutividade. Na região de floresta subtropical foi encontrada a maior riqueza média de espécies por trecho amostrado, enquanto nas regiões de floresta tropical foram observados os mais elevados valores de abundância de algas azuis. Testes de correlação revelaram que a condutividade foi significativa e negativamente relacionada às variações na abundância e riqueza das espécies de algas azuis. Este resultado provavelmente reflete a habilidade das cianofíceas em desenvolver-se em ambientes com média a baixa concentração de íons e, ao mesmo tempo, ter vantagens sob condições de estresse de nutrientes.

Key words - Cyanophyceae, ecological distribution, conductance, streams, Brazil

\section{Introduction}

Cyanophyceae (Cyanobacteria, Cyanoprokariota) are successful in a wide range of environments because they have a versatile metabolism and, in many cases, represent the dominant primary producers at the basis of the food web of ecosystems (Stal 1995). They are very common and important members of stream algal communities, in which many species have been ascribed as dominant or major

1. Unversidade Estadual Paulista Júlio de Mesquita Filho, Departamento de Zoologia e Botânica, R. Cristóvão Colombo, 2265, 15054-000 São José do Rio Preto, SP, Brasil.

2. Universidade Estadual do Centro Oeste (UNICENTRO) CEDETEG - Caixa postal 730, 85015-430 Guarapuava, PR, Brasil.

3. Corresponding author: branco@bot.ibilce.unesp.br functional components in several river systems throughout the world (Aboal 1989, Branco \& Necchi 1998, Sheath \& Cole 1992, Sheath et al. 1996, Whitton 1984). The most comprehensive survey of stream macroalgae carried out by Sheath \& Cole (1992) in 1,000 North American streams found the cyanophyte Phormidium retzii as the most widespread species in the continent.

Information about ecological distribution ranges of species complete the taxonomic knowledge with data on ecological requirements of each species, that is especially important for the taxonomy of blue-green algae (Komárek 1994) and, in addition, provide valuable data on the structure and function of lotic ecosystems. The distribution of cyanophytes is commonly influenced by many factors such as phosphorus, nitrogen, N/P ratio, light, oxygen and $\mathrm{pH}$ (Whitton 1992) and species vary in their ecological requirements (Perona et al. 1998). 
This research was made with the intention to improve our poor knowledge of the broad scale distribution patterns of stream blue-green algae in tropical (and sub-tropical) regions and to compare the ecological aspects of different regions in São Paulo State. It is expected that different regions have different ecological conditions (e.g. soil and climate), determining distinct vegetational types and water chemistry. According to literature data, factors potentially acting on cyanophyte occurrence (oxygen, turbidity, $\mathrm{pH}$, current velocity, conductance, and canopy cover) were investigated and the results were compared to other findings for different regions of the world.

\section{Material and methods}

The sampling program focused on the best preserved areas of São Paulo State, but some areas show impacts of various nature and intensities. 172 stream reaches (figure 1) distributed in the following regions (parts of biomes or selected geological areas) were sampled from June 1992 to September 1997: a) Atlantic rainforest, indicated as AF (54 stream segments), b) subtropical rainforest, indicated as $\mathrm{SF}$ (14 segments), c) northwest region of São Paulo State, containing cerrado (Brazilian savanna) and tropical rainforest (many sites considered impacted), indicated as NW (44 segments), d) cerrado, indicated as CE (16 segments), e) tropical rainforest, indicated as TF (22 segments), and f) hard water regions, spread throughout São Paulo State, indicated as HW (22 segments).

All the regions are under almost the same flow regime, characterized by two distinct seasons: one cold and dry and the other warm and rainy. The most conspicuous difference among geochemistry of the regions pertains to hard water regions, which drain calcareous rocks. Size and riparian vegetation of the streams are very variable among as well as throughout the regions; we preferentially sampled $2^{\text {nd }}$ to $3^{\text {rd }}$ order streams and with the best preserved riparian vegetation as possible.

Each stream segment was searched for macroscopic bluegreen algal plant masses (macroalgae - according to Sheath \& Cole 1992) and the most representative Cyanophyceae of algal communities were also included. Sites were sampled once since this has been showed to be satisfactory for the objectives of the studies in similar approaches (Branco \& Necchi Jr. 1996, Necchi Jr. et al. 1995, Sheath \& Cole 1992). Collecting trips were made from late autumn to early spring, i.e. during the dry season, which has been determined as the most favorable period for stream macroalgae in tropical regions (Necchi Jr. \& Pascoaloto 1993, Necchi Jr. et al. 1995). Seasonal precipitation rates are low at this period which favors more diversified communities (Necchi Jr. et al. 1995) and samplings were concentrated during the dry season to assure similar flow conditions for all areas, which improves the comparisons. Water temperature, specific conductance, turbidity, $\mathrm{pH}$, and oxygen saturation were measured with HORIBA U-10 water quality checker. Current velocity was measured using GENERAL OCEANICS current meter, at five equally spaced points

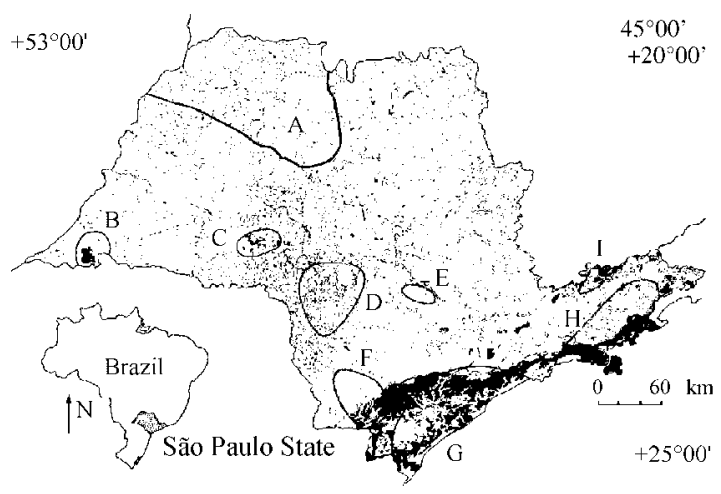

Figure 1. Map of São Paulo State (modified from Kronka et al. 1993) showing sampling regions (spots represent natural vegetation cover). A - Northwest region (NW), B - Tropical Rainforest (TF), C-D - Cerrado (CE), E-F - Hard Water regions (HW), G-H - Atlantic Rainforest (AF), and I - Subtropical Rainforest (SF).

along the reaches, as close as possible to the algal growth, and averaged.

The method applied to collect data and algal samples consisted of a search within a 10-m long stream reach (for further details see Necchi Jr. et al. 1995). Presence/absence and percentage cover of all taxa recognizable by naked eye were recorded throughout the reach. Zero occurrences were treated as absence of algae (community or population) or $0 \%$ of cover in a sampling site. Detailed information about preservation, analysis, and algal identification are provided in Branco et al. (1999), including taxonomic descriptions and ranges of species occurrence for the selected parameters.

Definitions of thallus types follow Sheath \& Cole (1992). Abundance (percent cover) and richness (number of taxa) of Cyanophyceae were related to physical and chemical stream parameters using the non-parametric Spearman's rank correlation $\mathbf{r}_{\mathrm{s}}$ (Zar 1996). Principal Coordinates Analysis (PCO - Digby \& Kempton 1987) was used in two ways: A. to group species with similar environmental preferences (quantitative parameters) using correlation coefficient, and $\mathrm{B}$. to discern algal groupings on the basis of environmental conditions of species occurrence, considering quantitative (physical and chemical parameters) and qualitative (occurrence in the regions) variables using Gower's coefficient. Quantitative parameters were standardized by ranging (maximum values) before matrix construction. Multiple regression analysis (Zar 1996) was conducted in order to find the most effective parameters acting on the distributional patterns of cyanophytes. Abundances of algae were firstly transformed by arcsine (Zar 1996) before analysis. Chi-square goodness-of-fit test (Zar 1996) was calculated between the frequency distribution of variables for streams (expected values), Cyanophyceae and the most frequent species, Phormidium retzii (observed values). Differences in means for species richness and abundance among regions were tested by one-way analysis of variance (ANOVA) (Zar 1996). Statistical analyses were performed using minitab statistical package (Ryan et al. 1985) and Syn-tax III (Podani 1989). 


\section{Results}

From a total of 172 stream reaches sampled in six regions of São Paulo State, 34 cyanophyte taxa were recorded (table 1). Cyanophytes were found as macroalgae in 77 reaches ( $44.8 \%$ of the total). In 62 sites $(80.5 \%$ of the total with occurrence of cyanophytes), only one species was observed, in 10 (13.0\%) two species were recorded, and in five $(6.5 \%)$ three taxa were found. The number of taxa

Table 1. Cyanophyceae occurrence in São Paulo State regions [abbreviations for figures 6 and 7]. AF - Atlantic Rainforest; NW - São Paulo State Northwest Region; TF - Tropical Rainforest; SF - Subtropical Rainforest; CE - Cerrado; HW - Hard Water Regions.

\begin{tabular}{|c|c|c|c|c|c|c|}
\hline Taxon & $\mathrm{AF}$ & NW & $\mathrm{TF}$ & SF & $\mathrm{CE}$ & HW \\
\hline Calothrix fusca [Cfusc] & & + & & & & \\
\hline Cylindrospermum minutissimum [Cminu] & & & & & + & \\
\hline Dichothrix baueriana [Dbau] & & & & + & & \\
\hline Geitlerinema splendidum [Gsple] & & + & & & & \\
\hline Gloeotrichia natans [Gnat] & & + & & & & \\
\hline Hapalosiphon flexuosus [Hflex] & & + & & & & \\
\hline Hapalosiphon stuhlmanii [Hstuhl] & & & & + & & \\
\hline Homoeothrix sp. [Homoeo] & & & + & & & \\
\hline Jaaginema homogeneum [Jhomog] & & & & + & & \\
\hline Leptolyngbya perelegans [Lperel] & & & & & + & \\
\hline Lyngbya major [Lmajor] & & & & + & & \\
\hline Lyngbya majuscula [Lmajusc] & + & & & & & \\
\hline Lyngbya martensiana [Lmart] & + & & & & & \\
\hline Lyngbya subconfervoides [Lsubc] & & & & + & & + \\
\hline Lyngbya sp.1 [Lsp1] & + & & & & & \\
\hline Lyngbya sp.2 [Lsp2] & & & & + & & \\
\hline Microcoleus subtorulosus [Msubt] & + & + & & + & & + \\
\hline Microcoleus vaginatus $[\mathrm{Mvag}]$ & & + & & & & \\
\hline Nostochopsis lobatus [Nlob] & + & & & & & \\
\hline Oscillatoria princeps [Oprinc] & & + & & & & \\
\hline Phormidium aerugineo-caeruleum [Pae-cae] & & + & & & & + \\
\hline Phormidium cf. cebennense [Pceb] & & & & & & + \\
\hline Phormidium irriguum [Pirrig] & + & + & & & & \\
\hline Phormidium puteale [Pput] & + & & & & & \\
\hline Phormidium retzii [Pretzii] & + & & + & + & & \\
\hline Phormidium cf. retzii [Pcfretz] & & + & + & & + & \\
\hline Phormidium schroederi [Pschr] & & & & + & & \\
\hline Phormidium willei [Pwillei] & & + & & + & & \\
\hline Plectonema cf. [Plecton] & & & & + & & \\
\hline Pleurocapsa fluviatilis [Pflu] & + & & & & & \\
\hline Rivularia cf. beccariana [Rbec] & & & & & + & \\
\hline Schizothrix cf. friesii [Sfries] & & & & & & + \\
\hline Scytonema arcangeli $[\mathrm{Sarc}]$ & + & + & + & + & & \\
\hline Stigonema robustum $[$ Srob] & & & + & & & \\
\hline Tolypothrix distorta [Tdist] & & + & & & & \\
\hline Overall & 10 & 13 & 5 & 12 & 4 & 5 \\
\hline
\end{tabular}



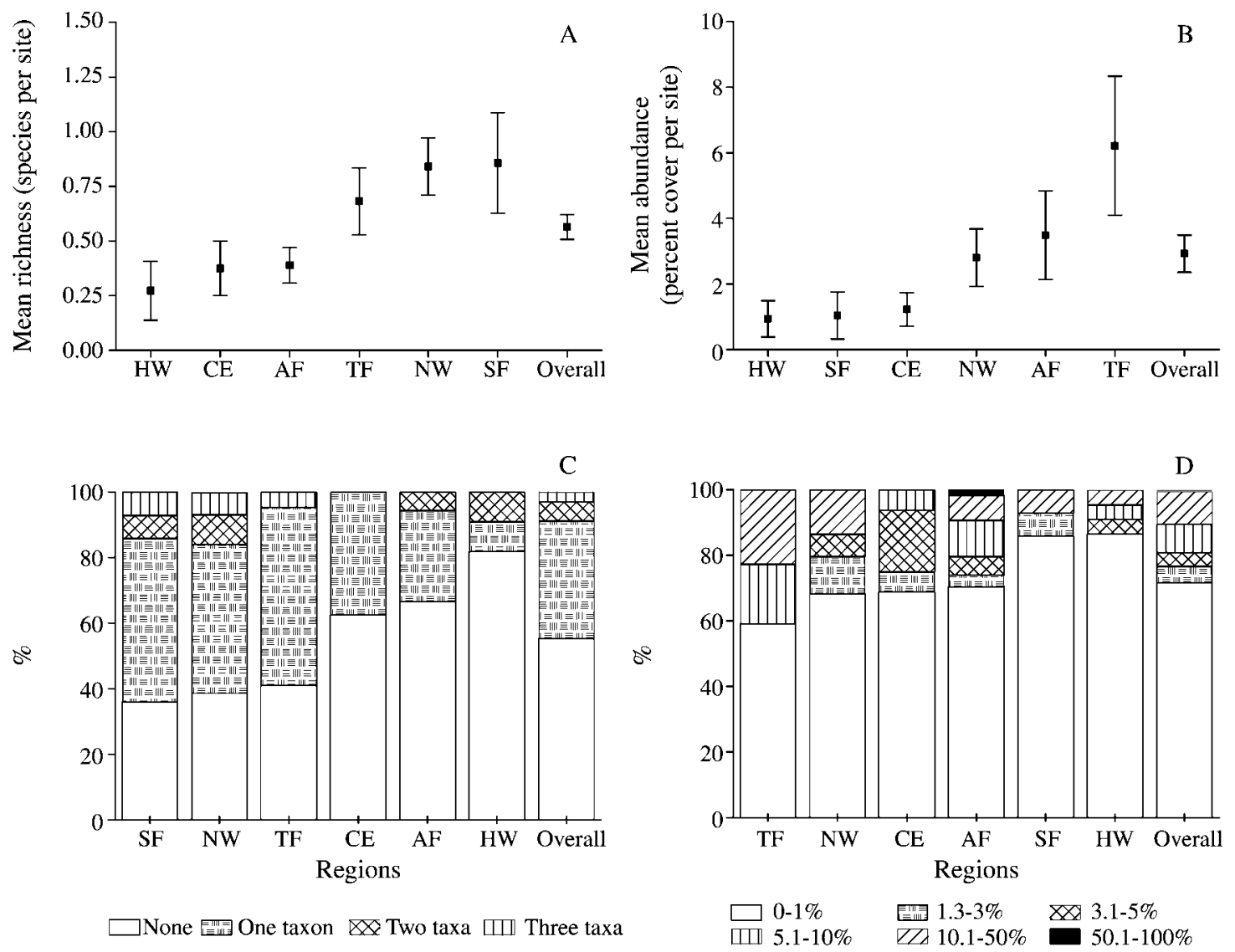

Figure 2. Mean richness (A) and abundance (B) per sampling site ( \pm one standard error). Percentage of sites with different number of taxa in each region and overall (C) and proportion of sites with distinct values of abundance (D) in each region and overall.

found in each region varied from four (CE) to 13 (NW) (table 1).

Mean richness per site was highest in SF and lowest in HW (figure 2A) and mean abundance per site was highest in TF, whereas HW, CE, and SF had lowest values (figure 2B). Some of the sampled reaches in TF had the highest abundances, and was the region with the greatest variability of blue-green algal cover. However SF and NW showed the highest average species richness per site. ANOVA did not reveal significant differences among regions for species richness $(\mathrm{F}=2.20 ; \mathrm{p}=0.06)$ and abundances $(\mathrm{F}=1.91 ; \mathrm{p}=0.10)$. The number of species per site in each region varied from 0 to 3 (figure 2C), and abundance per sampling ranged from $0 \%$ to $55 \%$ and macroscopic cyanophytes were absent in most sites of all regions (figure 2D). The comparison of species distribution among the regions (table 1 ) produced the following results: 26 taxa (76.5\%) were exclusive to a single region, five $(14.7 \%)$ occurred in two regions, two $(5.9 \%)$ in four regions, and one species (Phormidium retzii including $P$. cf. retzii - 2.9\%) was recorded in five regions. The NW had the highest number of taxa with exclusive occurrence (seven taxa) and hard water regions (HW) and tropical rainforest (TF) presented the lowest values for exclusive taxa (two).

Cyanophyceae occurred under a wide range of ecological parameters (table 2, figures 3-5). Correlations of Cyanophyceae and environmental parameters considering all regions together $(n=168$; excluding four sites with missing values from the total of 172 sites) show that abundance and conductance $\left(\mathrm{r}_{\mathrm{s}}=-0.21, \mathrm{p}<0.01\right)$, abundance and turbidity 
Table 2. Range, mean and standard deviation of blue-green algae occurrence under selected environmental parameters $(\mathrm{n}=77)$.

\begin{tabular}{lcccc}
\hline Parameter & Maximum & Minimum & Mean & Standard deviation \\
\hline Conductance $\left(\mu \mathrm{S} . \mathrm{cm}^{-1}\right)$ & 286.0 & 2.0 & 53.28 & 6.24 \\
Current velocity $\left({\left.\mathrm{cm} . \mathrm{s}^{-1}\right)}^{178.0}\right.$ & 90.0 & 0.0 & 47.69 & 29.67 \\
Oxygen $(\%)$ & 8.6 & 46.0 & 67.84 & 10.85 \\
$\mathrm{pH}$ & 27.8 & 5.3 & 6.86 & 0.58 \\
Temperature $\left({ }^{\circ} \mathrm{C}\right)$ & 35.0 & 0.0 & 19.94 & 3.07 \\
Turbidity $(\mathrm{NTU})$ & & 7.50 & 7.84 \\
\hline
\end{tabular}
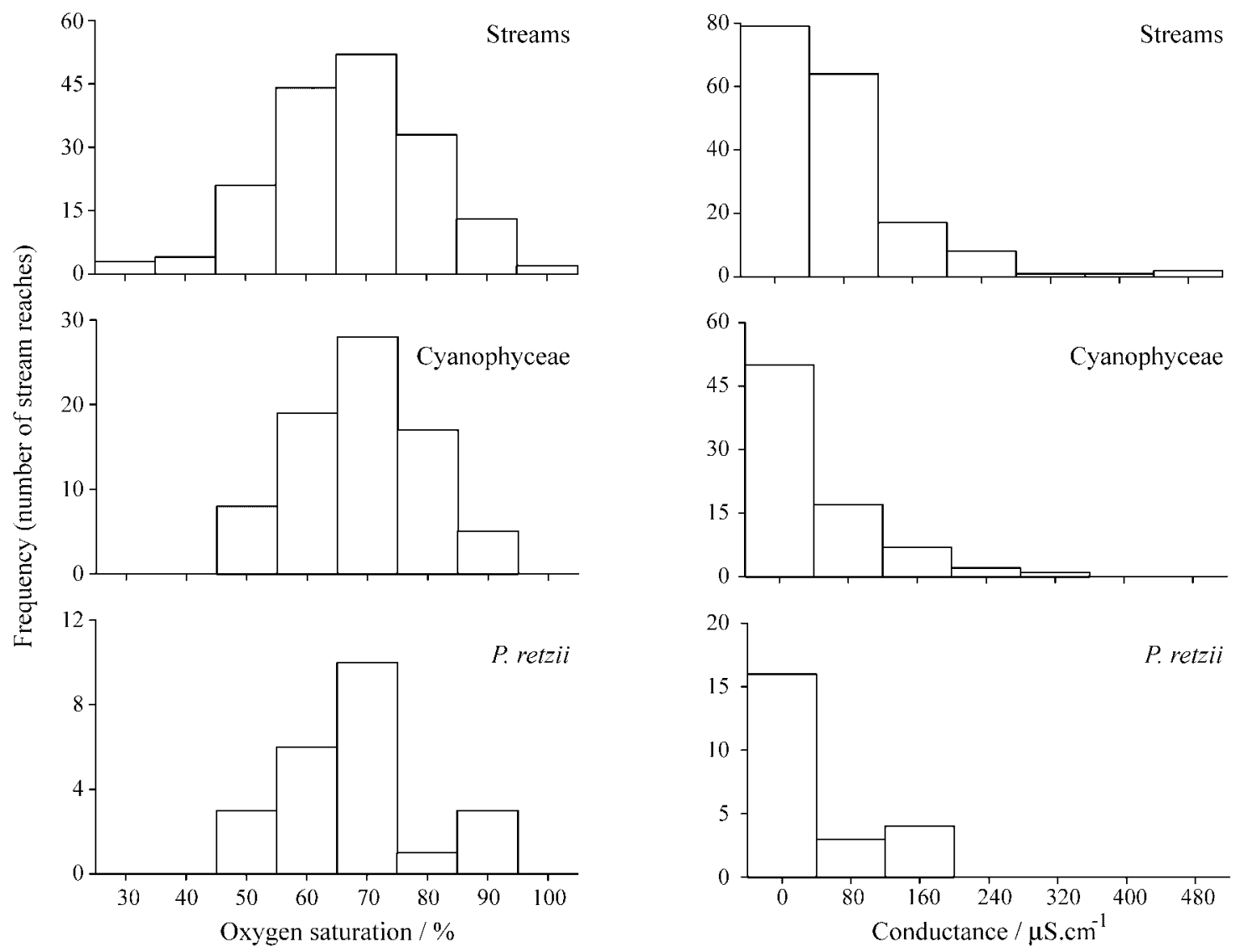

Figure 3. Frequency distribution of streams $(\mathrm{n}=172)$, cyanophytes $(\mathrm{n}=77)$ and Phormidium retzii $(\mathrm{n}=23)$ according to occurrence under oxygen concentration and conductance values found in São Paulo State.

$\left(\mathrm{r}_{\mathrm{s}}=-0.16, \mathrm{p}<0.05\right)$, abundance and oxygen $\left(r_{\mathrm{s}}=0.15, \mathrm{p}<0.05\right)$, richness and conductance $\left(r_{\mathrm{s}}=-0.19, \mathrm{p}<0.05\right)$ and richness and oxygen $\left(r_{\mathrm{s}}=0.19, \mathrm{p}<0.05\right)$ were significantly correlated. In addition, richness and abundance of cyanophytes were highly associated parameters $\left(r_{\mathrm{s}}=0.94\right.$, $\mathrm{p}<0.001)$. Abundance and richness of blue-green algae with ecological parameters considering regions separately revealed some statistically significant interactions for all regions (table 3 ). The most 

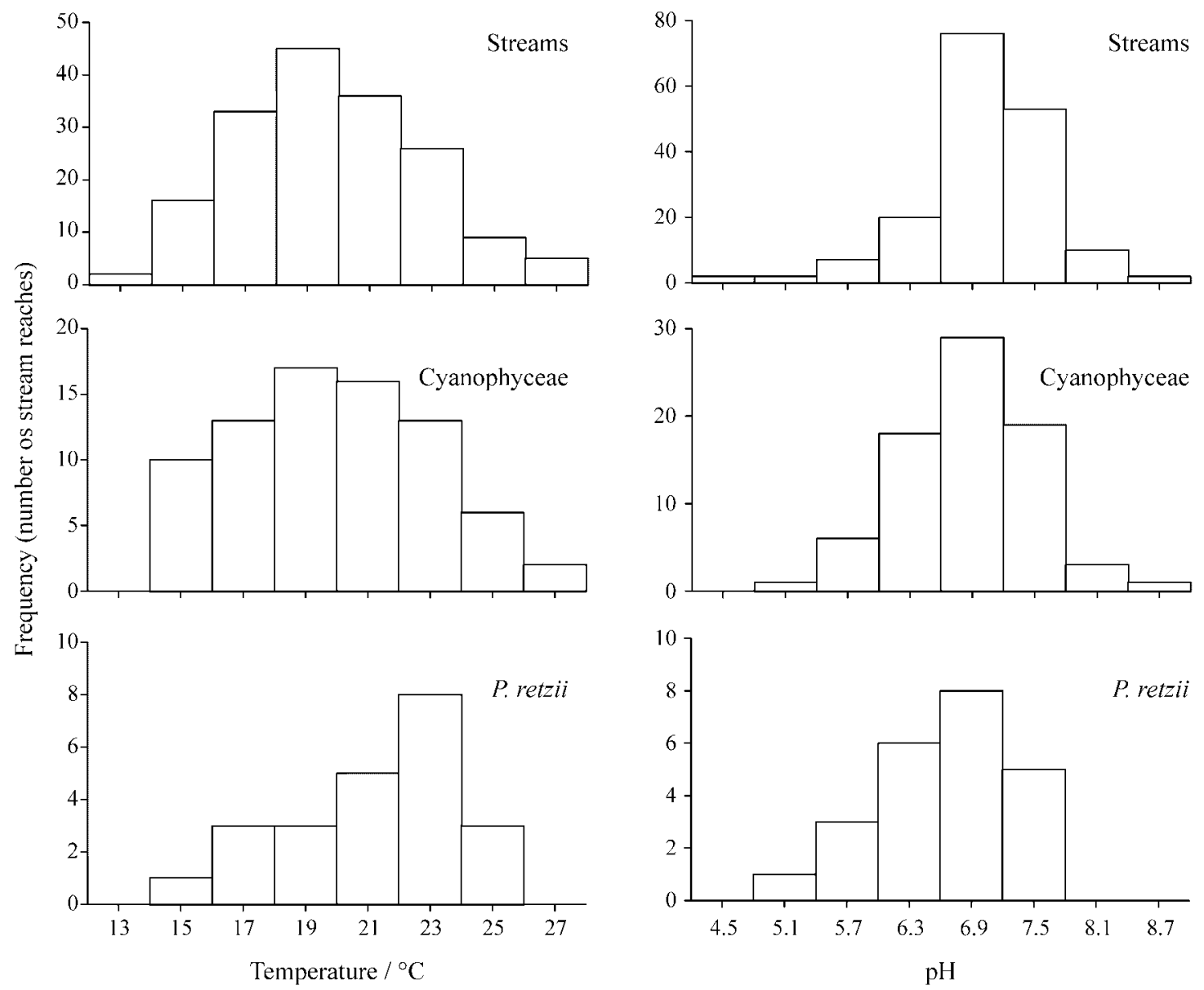

Figure 4. Frequency distribution of streams $(\mathrm{n}=172)$, cyanophytes $(\mathrm{n}=77)$ and Phormidium retzii $(\mathrm{n}=23)$ according to occurrence under temperature and $\mathrm{pH}$ values found in São Paulo State.

consistent correlations were observed between abundance and richness of cyanophytes (positive in all regions), abundance and conductance (negative in NW and TF; positive in HW), richness and conductance (negative in NW and TF; positive in $\mathrm{HW}$ ), abundance and oxygen (positive in AF, HW and $\mathrm{NW}$ ), and richness and oxygen (positive in $\mathrm{AF}$ and NW). Chi-square goodness-of-fit between streams and cyanophytes revealed no significant differences in distribution according to any evaluated physical and chemical characteristic considered. As well as, multiple regression analysis resulted in low explanation values (only $8.1 \%$ of all variations in abundance of cyanophytes) considering all parameters together.

Phormidium retzii was the most widespread species occurring in all regions, except in HW, al- though the chi-square comparison between that species and streams ecological distribution (figures 3-5) differ significantly for temperature $\left(\mathrm{X}^{2}=16.88\right.$, $\mathrm{p}<0.01)$, current velocity $\left(\mathrm{X}^{2}=13.12, \mathrm{p}<0.05\right)$, and oxygen saturation $\left(\mathrm{X}^{2}=15.84, \mathrm{p}<0.01\right)$. Spearman's rank correlation $r_{s}$ resulted no significant values between $P$. retzii abundance (including $P$. cf. retzii) and environmental parameters. Frequency distributions (figures 3-5) show that $P$. retzii occurs preferentially at low values of conductance $(<50 \mu \mathrm{S}$. $\mathrm{cm}^{-1}$ ), turbidity ( $\left.<15 \mathrm{NTU}\right)$, current velocity $\left(<68 \mathrm{~cm} \cdot \mathrm{s}^{-1}\right)$, and $\mathrm{pH}(5.5$ to 7.5$)$. Intermediate values of oxygen saturation (55 to $75 \%$ ) and water temperature ( 19 to $23{ }^{\circ} \mathrm{C}$ ) seem also to be favorable to this species occurrence. 

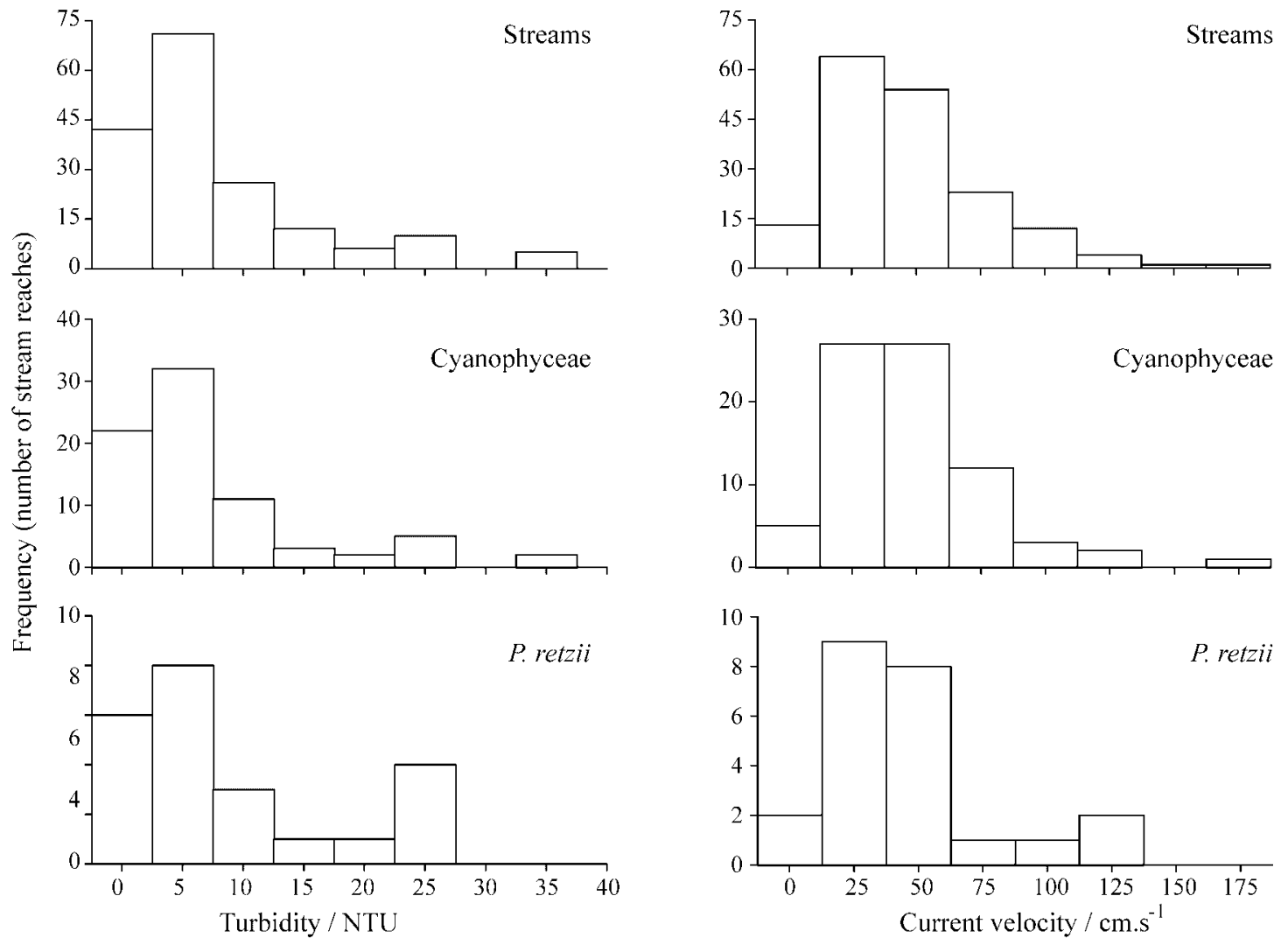

Figure 5. Frequency distribution of streams $(n=172)$, cyanophytes $(n=77)$ and Phormidium retzii $(n=23)$ according to occurrence under turbidity and current velocity values found in São Paulo State.

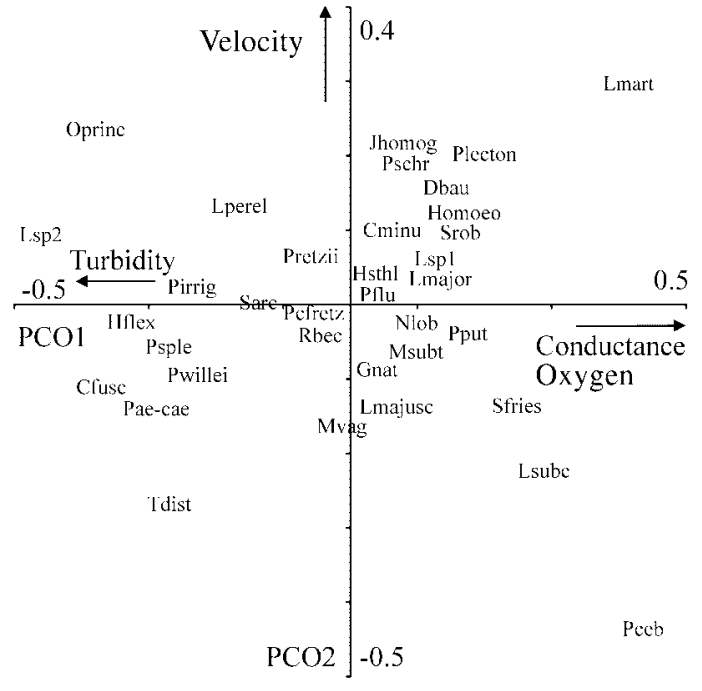

Figure 6. Principal coordinate analysis (PCO) plot for species grouping on the basis of quantitative parameters (abbreviations according to table 1).
Mat (entangled filaments) was the commonest thallus type found (63.6\% or 21 taxa), followed by tuft ( $24.2 \%$ or eight taxa), gelatinous colony $(9.1 \%$ or three taxa), and crust (3.1\% or one taxon).

Principal coordinate analysis (PCO), on the basis of occurrence of cyanophytes considering mean values of environmental parameters (figure 6), shows that conductance, oxygen saturation, and turbidity (PCO1) produced $52.9 \%$ of variation in species distribution, while current velocity ( $\mathrm{PCO} 2$ ) accounted for $23.8 \%$ of variations.

On the basis of qualitative (region of occurrence) and quantitative data (environmental occurrence) simultaneously, PCO resulted in five groups (figure 7). Group A is characterized by species occurrence in NW, very high turbidity (6-21 NTU, $\overline{\mathrm{X}}=14)$ and temperature $\left(22.9-24.4{ }^{\circ} \mathrm{C}, \overline{\mathrm{X}}=23\right)$ values and high conductance $\left(25-117 \mu{\mathrm{S} . \mathrm{cm}^{-1}}^{-1}\right.$ 
Table 3. Significant correlations (Sperman's $\mathrm{r}_{\mathrm{s}}$ ) between cyanophytes abundance and richness with selected environmental parameters in the regions of São Paulo State. $* \mathrm{p}<0.05$, ** $\mathrm{p}<0.01$, $* * * \mathrm{p}<0.001$. AF - Atlantic Rainforest; CE - Cerrado; HW - Hard Water Regions; NW - São Paulo State Northwest Region; SF Subtropical Rainforest; TF - Tropical Rainforest.

\begin{tabular}{|c|c|c|}
\hline & Parameters & $r_{s}$ \\
\hline $\mathrm{AF}$ & abundance $v s$. oxygen & $0.3467 *$ \\
\hline \multirow[t]{2}{*}{$(\mathrm{n}=50)$} & richness $v s$. oxygen & $0.3616^{*}$ \\
\hline & abundance $v s$. richness & $0.9125 * * *$ \\
\hline \multicolumn{3}{|l|}{$(n=16)$} \\
\hline HW & abundance $v s$. conductance & $0.4531^{*}$ \\
\hline \multirow[t]{7}{*}{$(\mathrm{n}=22)$} & abundance $v s$. current velocity & $0.4429 *$ \\
\hline & abundance $v s . \mathrm{pH}$ & $0.5064^{*}$ \\
\hline & abundance $v s$. oxygen & $0.4573 *$ \\
\hline & richness $v s$. conductance & $0.4508^{*}$ \\
\hline & richness $v s$. current velocity & $0.4621 *$ \\
\hline & richness $v s . \mathrm{pH}$ & $0.5324 *$ \\
\hline & abundance $v s$. richness & $0.9943 * * *$ \\
\hline NW & abundance $v s$. conductance & $-0.3169^{*}$ \\
\hline \multirow[t]{5}{*}{$(n=44)$} & abundance $v s$. oxygen & $0.3147^{*}$ \\
\hline & abundance $v s$. turbidity & $-0.3176^{*}$ \\
\hline & richness $v s$. conductance & $-0.3461^{*}$ \\
\hline & richness vs. oxygen & 0.3659 \\
\hline & abundance $v s$. richness & $0.9214 * * *$ \\
\hline SF & abundance $v s . \mathrm{pH}$ & $-0.6043^{*}$ \\
\hline$(\mathrm{n}=14)$ & abundance $v s$. richness & $0.8549 * * *$ \\
\hline $\mathrm{TF}$ & abundance $v s$. conductance & $-0.7046^{* * *}$ \\
\hline \multirow[t]{3}{*}{$(\mathrm{n}=22)$} & abundance $v s . \mathrm{pH}$ & $-0.4887 *$ \\
\hline & richness $v s$. current velocity & $0.6188 * *$ \\
\hline & abundance $v s$. richness & $0.8726^{* * *}$ \\
\hline
\end{tabular}

$\overline{\mathrm{X}}=81)$. Group B contains species mainly occurring in $\mathrm{AF}$ (except Phormidium willei) and under low values of turbidity (0.4-11.7 NTU, $\bar{X}=4.4)$. C is formed by taxa from $\mathrm{CE}$, present in low conductance (9-36 $\left.\mu{\mathrm{S} . \mathrm{cm}^{-1}}^{-1} \overline{\mathrm{X}}=21\right)$ and high turbidity (5-23 NTU, $\bar{X}=11.5$ ). Group D is formed by species occurring in SF, under very low conductance (2$\left.19 \mu{\mathrm{S} . \mathrm{cm}^{-1}}^{-}, \overline{\mathrm{X}}=7.5\right)$ and low $\mathrm{pH}(5.9-7.4, \overline{\mathrm{X}}=5.7)$, and turbidity (3-7 NTU, $\bar{X}=4.8)$. Finally, group E is composed by species found in $\mathrm{HW}$, growing under the lowest value of turbidity ( $\overline{\mathrm{X}}=1 \mathrm{NTU})$ and the highest of conductance (89-286 $\mu$ S.cm $\left.{ }^{-1}, \bar{X}=181.5\right)$.

\section{Discussion}

Despite the pronounced difference in sampling area, relative comparison between the present results and those found by Sheath \& Cole (1992) reveals that cyanophytes are more frequent in São Paulo State streams (44.8\% of total streams sampled) than in North America streams (12.2\% of 1,000 stream segments). We found 34 blue-green algal taxa versus 62 taxa in the North American continent. Aboal (1989) sampled 37 reaches throughout River Segura Basin (Spain) and found 45 taxa, but the author considered all taxa present, whereas we evaluated only the macroscopic plant masses. We focused on the most abundant species in each mass because, although many different species of blue-green algae have been found in microbial mats, most were dominated by one species (Stal 1995).

Conductance is ascribed as a variable which integrates several higher-level watershed processes and explains considerably more variance in the periphyton than any other variable (Biggs 1990). The statistically significant values found for correlation between conductance and cyanophyte abundance and richness corroborate this relationship. According to Biggs (1990), conductance has no direct mode of action on the periphyton, but indicates the relative level of nutrient supply available to the communities. Our data suggests that stream blue-green algae (mostly mat forming) are more competitive in medium-low nutrient levels than at high concentrations.

Some studies indicate that blue-green algal frequency and abundance tend to be higher with increasing pH values (e.g. Shapiro 1973, Whitton 1992). We found the lowest values for abundance and very low values for richness in hard water regions, which is the sampled area with highest $\mathrm{pH}$ and conductance. At the present stage, we are not able to propose any explanation of why the distribution pattern found is quite different from those described in literature (e.g. Shapiro 1973, Whitton 1992). Maybe the answer for this relationship can be found in the chemical composition of the high conductance waters, but the available data can not support such approach.

The lack of significant differences for species richness and abundance among biomes/regions indicated by this investigation is contrary to our initial 


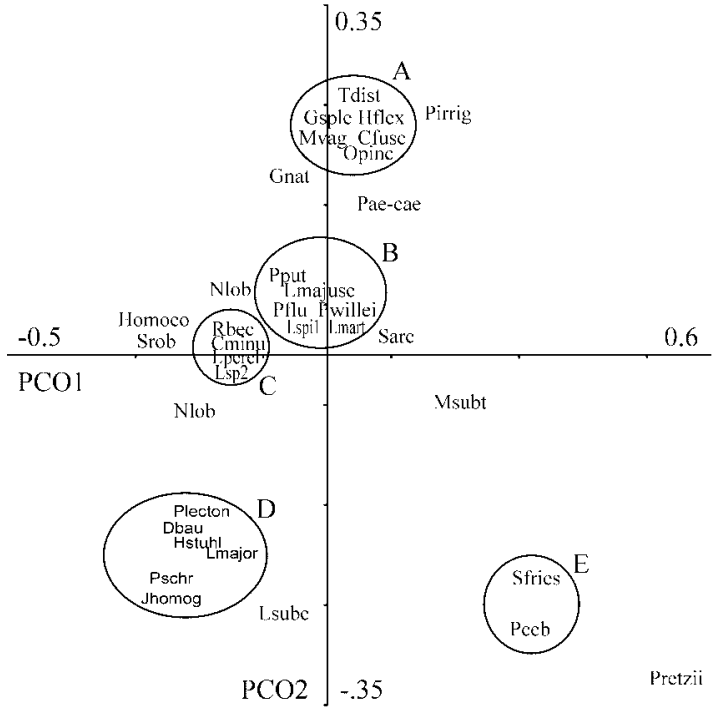

Figure 7. Principal coordinate analysis (PCO) plot for species grouping on the basis of quantitative and qualitative parameters (abbreviations according to table 1).

hypothesis and reveals a relatively global homogeneity in cover and richness of cyanophytes. Similar result was also found for Rhodophyta (Necchi Jr. et al. 1999) and this approach would be a relevant topic to be evaluated for other algal groups for determining if it is a general pattern in lotic ecosystems in São Paulo State.

The dominance of mats over other thallus types occurs among blue-green algae and confirms data from Sheath \& Cole (1992). Cyanophytes are important components of microbial mats (association with bacteria and other algae, mainly diatoms) and form a very productive plant mass (Stal 1995, Stock \& Ward 1991). Mats are very common among bluegreen algae and this thallus type has been considered an adaptation to avoid current breaking stress in lotic ecosystems (Sheath \& Hambrook 1990).

Phormidium retzii was the most widespread species in São Paulo State streams. This species was found to be the most frequent in North America, but compiled data for Europe differ from these observations, according to Sheath \& Cole (1992). The authors emphasize that this difference between the two continents is not due to taxonomic interpretation, because their concept of $P$. retzii is based on the same specific literature. The preference of $P$. retzii in inhabiting low conductance streams is in accord- ance with pattern showed for this taxon by Sheath \& Cole (1992) and its few records could be associated to high conductance commonly found in most European waters.

In summary, cyanophyte richness and abundance in São Paulo State streams are related to conductance, since negative correlations were found for single regions and considering all regions together. This relationship possibly may reflect the ability of blue-green algae to grow at medium to low ion contents and their competitive advantage under nutrient stress conditions in running waters.

This study comprises a first step in understanding blue-green algae distribution in tropical (and subtropical) running waters and more detailed investigations must be conducted. We suggest that further studies should be focused on the evaluation of the specific responses to environmental nutrient content, especially $\mathrm{N}$ and $\mathrm{P}$ and their availability in relation to carbon supply, that have been ascribed as important factors for cyanophyte occurrence in temperate regions of the world.

Acknowlegements - This research was supported by CNPq (research grants to L.H.Z.B., 300128/97-5, and to ONJ, 300379/862), and FAPESP (grant-in-aid to O.N.J., 95/2758-8). We are indebted to Dr. Brian A. Whitton (University of Durham) for valuable comments and to Dr. James Robert Coleman (IBILCE/UNESP) from reviewing the text.

\section{References}

ABOAL, M. 1989. Epilithic algal communities from River Segura Basin, Southeastern Spain. Archiv für Hydrobiologie 116:113-124.

BIGGS, B.J.F. 1990. Periphyton communities and their environments in New Zealand rivers. New Zealand Journal of Marine and Freshwater Research 24:367-386.

BRANCO, C.C.Z. \& NECCHI JR., O. 1996. Survey of stream macroalgae of eastern Atlantic Rainforest of São Paulo State, southeastern Brazil. Algological Studies 80:35-57.

BRANCO, L.H.Z. \& NECCHI JR., O. 1998. Distribution of macroalgae in three tropical drainage basins of southeastern Brazil. Archiv für Hydrobiologie 142:241-256.

BRANCO, L.H.Z., NECCHI JR., O. \& BRANCO, C.C.Z. 1999. Cyanophyceae from lotic ecosystems of São Paulo State, southeastern Brazil. Algological Studies 94:63-87.

DIGBY, P.G.N. \& KEMPTON, R.A. 1987. Multivariate analysis of ecological communities. Chapman \& Hall, London.

KOMÁREK, J. 1994. Current trends and species delimitation in the cyanoprokaryote taxonomy. Algological Studies 75:11-29. 
KRONKA, F.J.N.,MATSUKUMA, C.K., NALON, M.A.,CALI, I.H., ROSSI, M., MATTOS, I.F.A., SHIN-IKE, M.S. \& PONTINHAS, A.A.S. 1993. Inventário florestal do estado de São Paulo. Instituto Florestal, São Paulo.

NECCHI JR., O., BRANCO, C.C.Z. \& BRANCO, L.H.Z. 1999. Distribution of Rhodophyta in streams from São Paulo State, southeastern Brazil. Archiv für Hydrobiologie: 147:73-89.

NECCHI JR., O., BRANCO, C.C.Z., SIMÃO R.C.G. \& BRANCO, L.H.Z. 1995. Distribution of stream macroalgae in the northwest region of São Paulo State, southeastern Brazil. Hydrobiologia 229:219-230.

NECCHI JR., O. \& PASCOALOTO, D. 1993. Seasonal dynamics of macroalgal communities in the Preto River basin, São Paulo, southeastern Brazil. Archiv für Hydrobiologie 129:231-252.

PERONA, E., BONILLA, I. \& MATEO, P. 1998. Epilithic cyanobacterial communities and water quality: an alternative tool for monitoring eutrophication in the Alberche River (Spain). Journal of Applied Phycology 10:183-191.

PODANI, J. 1989. Syn-tax III - PC. Computer programs for data analysis in ecology and systematics. User's manual. ICEM, Trieste.

RYAN, B.F., JOINER, B.L. \& RYAN JR, T.A. 1985. Minitab handbook. 2 ed. Duxbury Press, Boston.
SHAPIRO, J. 1973. Blue-green algae: why they become dominant. Science 179:382-384.

SHEATH, R.G. \& COLE, K.M. 1992. Biogeography of stream macroalgae in North America. Journal of Phycology 28:448-460.

SHEATH, R.G. \& HAMBROOK, J.A. 1990. Freshwater ecology. In Biology of the Red Algae (K.M. Cole \& R.G. Sheath, eds.). Cambridge University Press, Cambridge, p.423-453.

SHEATH, R.G., VIS, M.L., HAMBROOK, J.A. \& COLE K.M. 1996. Tundra stream macroalgae of North America: composition, distribution and physiological adaptations. Hydrobiologia 336:67-82.

STAL, J. 1995. Tansley Review N. 84: Physiological ecology of cyanobacteria in microbial mats and other communities. New Phytologist 131:1-32.

STOCK, M.S. \& WARD, A.K. 1991. Blue-green algal mats in a small stream. Journal of Phycology 27:692-698.

WHITTON, B.A. 1984. Ecology of European Rivers. Blackwell Scientific, Oxford.

WHITTON, B.A. 1992. Diversity, Ecology, and Taxonomy of the Cyanobacteria. 1-15. In Photosynthetic Prokariotes (N.H. MANN \& N.G. CARR, eds.). Plenum Press, New York.

ZAR, J.H. 1996. Biostatistical analysis. 3 ed. Prentice-Hall, Upper Saddle River. 